Sains Malaysiana 46(3)(2017): 457-461

http://dx.doi.org/10.17576/jsm-2017-4603-13

\title{
Detection of Naringenin and Kaempferol in Justicia gendarussa Leaf Extracts by GC-FID
}

(Pengesanan Naringenin dan Kaempferol dalam Ekstrak Daun Justicia gendarussa oleh GC-FID)

\author{
ZAHIDAH AYOB, SHAJARAHTUNNUR JAMIL, Siti PAULIENA MOHD BOHARI, \\ FAREDIAH AHMAD \& AZMAN ABD SAMAD*
}

\begin{abstract}
Justicia gendarussa methanolic leaves extract from four different locations in Southern region of Malaysia and distribution of two flavonoids, naringenin and kaempferol in plant organs (young and mature leaves) were determined using gas chromatography-flame ionization detector (GC-FID) analysis. Naringenin and kaempferol contents were detected and quantified in leaves extract. The results indicated that mature leaves contained more naringenin and kaempferol compared to young leaves. The highest concentration of naringenin and kaempferol were recorded in mature leaves from Skudai and Muar regions which were 507.692 and $1226.964 \mathrm{mgkg}^{-1}$, respectively. Data analysis showed that naringenin content was directly proportional to the amount of kaempferol in the leaf extracts. In conclusion, this study suggested geographical variation among plant samples and physiological stage of organ parts could contribute to variation in flavonoids concentration in a plant species.
\end{abstract}

Keywords: Flavonoids; GC-FID; Justicia gendarussa; kaempferol; naringenin

\section{ABSTRAK}

Ekstrak daun Justicia gendarussa menggunakan metanol daripada empat lokasi berbeza di wilayah selatan Malaysia dan taburan dua sebatian flavonoid, naringenin dan kaempferol dalam organ-organ tumbuhan (daun muda dan tua) telah ditentukan dengan menggunakan analisis Gas Kromatografi-Pengesan Pengionan Nyala (GC-FID). Kandungan naringenin dan kaempferol telah dikesan dan ditentukan dalam ekstrak daun. Keputusan kajian menunjukkan bahawa daun tua mengandungi lebih naringenin dan kaempferol berbanding daun muda. Kepekatan tertinggi naringenin dan kaempferol telah dicatatkan pada daun tua dari kawasan Skudai dan kawasan Muar yang masing-masing adalah 507.692 dan $1226.964 \mathrm{mgkg}^{-1}$. Analisis data menunjukkan kandungan naringenin adalah berkadar terus dengan amaun kaempferol pada ekstrak daun. Kesimpulannya, kajian ini mencadangkan variasi geografi dalam kalangan sampel tumbuhan dan tahap fisiologi bahagian organ boleh menyumbang kepada variasi kepekatan flavonoid pada spesies tumbuhan.

Kata kunci: Flavonoid; GC-FID; Justicia gendarussa; kaempferol; naringenin

\section{INTRODUCTION}

Justicia gendarussa or known as Gendarussa is a member of Acanthaceae family. This species is distributed in many countries including Indonesia, Sri Lanka, India and Malaysia. J. gendarussa plant is an erect, branched, smooth undershrub, $0.8-1.5 \mathrm{~m}$ in height with long leaves (7 to $14 \mathrm{~cm}$ ) having acute tips, small flowers, terminal pinkish spikes with purple spots (Thomas \& Yoichiro 2010). The root and leaves extracts of J. gendarussa have been used traditionally to treat many ailments such as chronic rheumatism, inflammations, bronchitis, headache, arthritis, vaginal discharges, dyspepsia, eye disease and fever (Janarthanam \& Sumathi 2010). Leaves and stem extracts of J. gendarussa were reported to possess anticancer, anti-inflammatory, antioxidant, antibacterial, antifungal, antiangiogenis, antiplatelet and hepatoprotective activities (Ayob et al. 2014, 2013; Krishna et al. 2010a, 2010b; Periyanayagam et al. 2009; Sharma et al. 2011; Subramanian et al. 2012). Phytochemical analysis on leaves of $J$. gendarussa has showed the presence of flavonoids, alkaloids, amino acids, triterpenoid saponins, aromatics amines, triterpenoid (stigmasterol, lupeol and 16-hydroxylupeol) (Bambang Prajogo et al. 2009; Chakravarty et al. 1981; Mustafa et al. 2010).

Naringenin and kaempferol are flavonoids that have strong anticancer activity in MCF-7, MDA-MB-231 and MDA-MB-468 breast cancer cells and also HT-29, HeLa and BxPC-3 human cancer cells (Ayob et al. 2014, 2013). There are also possess high antioxidant activity and exhibit inhibitory effects on cholesterol in HepG2 and MCF-7 cancer cells (Cavia-Saiz et al. 2010; Kim et al. 2008; Zhang et al. 2008). For instance, naringenin demonstrated suppressed apoptotic in mouse leukaemia P388 cells while kaempferol has been reported to inhibit cell proliferation, induce apoptosis to pancreatic cancer cells (MIAPaCa-2 and Panc-1) and prevented arteriosclerosis (Kanno et al. 2005; Tu et al. 2007; Zhang et al.2008). Several flavonoids have been detected in plant extracts of J.gendarussa using 
high performance liquid chromatography (HPLC) (Mustafa et al. 2010). In addition, a simple and efficient method for detection and quantification of naringenin and kaempferol from fresh crude extracts of Melastoma decemfidum using GC-FID has been reported (Sarju et al. 2012). Hence, to the best of our knowledge, this is the first study of the detection and quantification of naringenin and kaempferol from young and mature leaves in J. gendarussa from different locations in southern region of Peninsular Malaysia using GC-FID.

\section{MATERIALS AND METHODS}

\section{PLANT MATERIAL}

$J$. gendarussa plants were collected from four different locations in Johor (Skudai, Batu Pahat, Mersing and Muar) and maintained in a glasshouse at Faculty of Biosciences and Medical Engineering, Universiti Teknologi Malaysia. The J. gendarusa plant was identified by Dr. Richard Chung Cheng Kong, a senior research officer of the Forest Research Institute of Malaysia (FRIM) and the voucher specimen (PID-100214-06) was deposited at the Herbarium Management Branch, Forest Biodiversity Division, FRIM, Kepong, Selangor, Malaysia.

\section{STANDARD REFERENCE, SAMPLES, SOLVENT AND EXTRACTION}

The commercial standard of naringenin and kaempferol were purchased from Sigma-Aldrich (Subang Jaya, Selangor, Malaysia). Standard solution for each compounds were prepared at concentration of $1 \mathrm{mgmL}^{-1}$. Twenty-four plants of $J$. gendarussa were bought from four nurseries in southern region of Peninsular Malaysia. Fresh of young and mature leaves (5.0 g of each plant) were crushed into a powder in liquid nitrogen. The powdered samples $(1.0 \mathrm{~g})$ were macerated in methanol $(3.0 \mathrm{~mL})$ and shaken at 150 rpm for $60 \mathrm{~min}$ at room temperature. Each extract was filtered through $0.2 \mu \mathrm{m}$ nylon syringe filter into Agilent's vial prior to GC-FID analysis.

\section{DETECTION AND QUANTIFICATION OF FLAVONOID}

GC-FID and quantitative analyses were carried out according to previously published method (Sarju et al. 2012). A gas chromatograph (HP-6890N, Agilent, USA) equipped with an HP-5 fused silica capillary column $(30.0 \mathrm{~m} \times 0.32 \mathrm{~mm}$ i.d., film thickness $0.25 \mu \mathrm{m}$ ) was used. The temperature programmed was $100-275^{\circ} \mathrm{C}$ at $10^{\circ} \mathrm{C} \mathrm{min}{ }^{-1}$ and $17 \mathrm{~min}$ hold at $275^{\circ} \mathrm{C}$. Initial temperature was $100^{\circ} \mathrm{C}$, injection temperature was $220^{\circ} \mathrm{C}$ and detector temperature was $270^{\circ} \mathrm{C}$. The flow rate of the carrier gas (helium) was $1 \mathrm{~mL}$ $\mathrm{min}^{-1}$. A split ratio of 50:1 was used. Exactly $5 \mu \mathrm{L}$ of crude extracts and standards were injected using a microsyringe. The chromatographic data were recorded and processed using Agilent Cerity QA-QC software.

\section{STATISTICAL ANALYSIS}

All experiments were carried out in triplicates. The data was analyzed statistically using SPSS software (SPSS 16.0, SPSS Inc., USA). The analyses involved Independence $t$-test and one-way ANOVA with post-hoc multiple comparisons i.e. Bonferroni test. The correlations were analyzed using Pearson correlation test (Pallant 2007).

\section{RESULTS AND DISCUSSION}

\section{QUALITATIVE ANALYSIS}

Phytochemical analysis on methanolic leaves extracts of $J$. gendarussa showed that naringenin and kaempferol were detected in samples collected from four different locations in Johor, Malaysia and distributed in both organ parts i.e. young and mature leaves. Figure 1 shows the chromatogram where two peaks of naringenin and kaempferol and their retention times are listed in Table 1 for qualitative identification. The two compounds were separated within $35.5 \mathrm{~min}$ with the baseline separation. Figure 2 shows the chromatograms of untreated mature leaf extract from Muar region (a) and after co-injected with two standards (b). The results indicated that naringenin and kaempferol were successfully detected in the leaf extracts of J.gendarussa.

\section{QUANTITATIVE ANALYSIS OF FLAVONOIDS IN LEAVES EXTRACTS}

In this study, distributions of naringenin and kaempferol contents in young leaves (second leaves from shoots) and mature leaves (seven to nine leaves from shoots) from four different locations of $J$. gendarussa have been evaluated. The results indicated that the mature leaves have higher naringenin and kaempferol contents compared to the young leaves. The highest concentration of naringenin and kaempferol were recorded in the mature leaves from Skudai region (507.692 $\left.\mathrm{mgkg}^{-1}\right)$ and Muar region (1226.964 $\mathrm{mgkg}^{-1}$ ), respectively (Figure 3 ). Naringenin content was directly proportional to the kaempferol contents in the leaf extracts. In addition, there was significant difference $(p<0.05)$ of both flavonoids in leaf extracts from four different locations. Both flavonoids contents were affected by different locations and organ parts. The findings suggested that flavonoid contents might be attributed to different in physiological, environmental and geographical, soil and genetic factors (Figueiredo et al. 2008; Kong et al. 2013; Salimon et al. 2010). Previous report demonstrated that kaempferol was not detected by HPLC method (Krishna et al. 2010b). This could be due to the fact that flavonoid such as kaempferol is produced at certain plant parts and development stages of plant (Figueiredo et al. 2008).

Based on flavonoid biosynthetic pathway, naringenin is synthesized at earlier stage and catalyzed by chalcone isomerase (CHI). Naringenin is then further hydroxylated into dihydrokaempferol, which finally converted to 


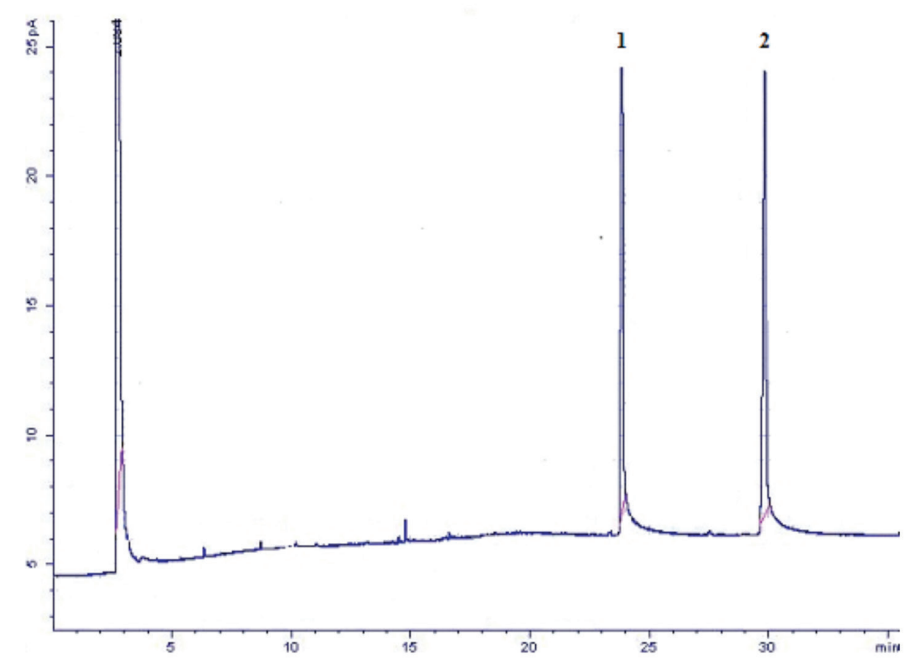

FIGURE 1. GC chromatogram of a standard mixture of two flavonoids. Column: HP-5 (30 m $\times 0.32 \mathrm{~mm}$ i.d. and df $0.25 \mu \mathrm{m})$; column temperature program: $100^{\circ} \mathrm{C}$ (hold $1 \mathrm{~min}$ ), then ramped to $275^{\circ} \mathrm{C}$ at $10^{\circ} \mathrm{C} \mathrm{min}{ }^{-1}$ and hold for $17 \mathrm{~min}$; injector port temperature: $220^{\circ} \mathrm{C}$; detector port temperature: $270^{\circ} \mathrm{C}$; carrier gas: helium at $1 \mathrm{~mL} \mathrm{~min}^{-1}$; detector: FID. Peaks: Naringenin (1) and Kaempferol (2)

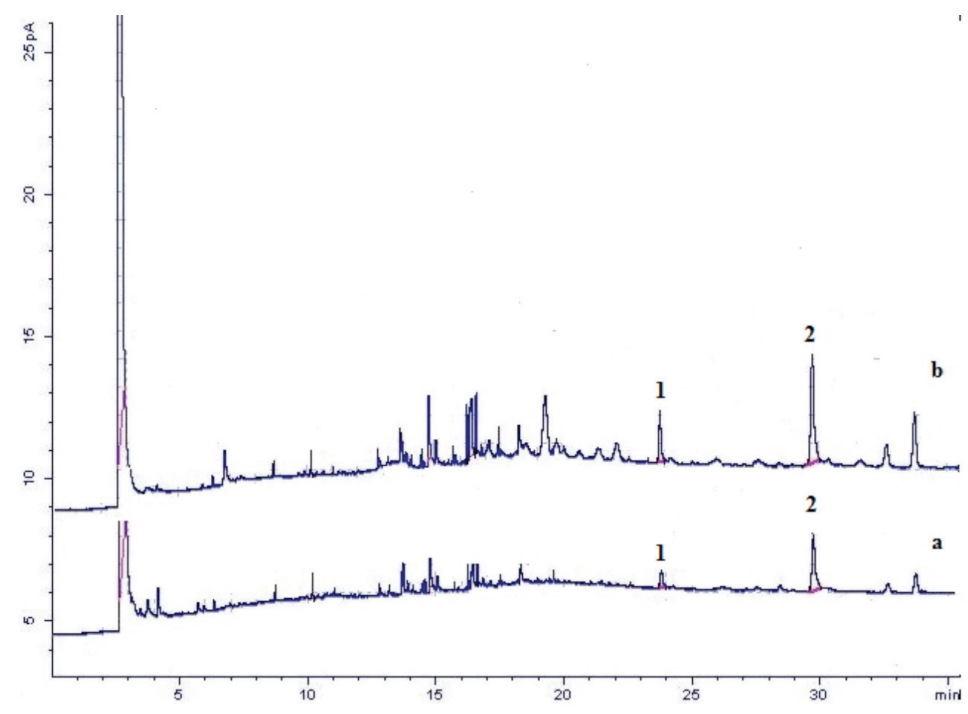

FIGURE 2. Chromatogram of naringenin and kaempferol contents in (a) mature leaves extract from Muar (control) and (b) co- injected with standards (naringenin and kaempferol)

TABLE 1. Retention times, $t_{\mathrm{R}}$ of naringenin an kaempferol on HP-5 column

\begin{tabular}{ccc}
\hline Peaks & Compounds & $\begin{array}{c}\text { Retention time, } \\
\mathrm{t}_{\mathrm{R}}(\min )\end{array}$ \\
\hline $\mathbf{1}$ & Naringenin & 23.865 \\
$\mathbf{2}$ & Kaempferol & 29.828 \\
\hline
\end{tabular}

kaempferol (flavonol) by flavonol synthases (FLS) (Forkmann 1991). It is suggested that naringenin is converted into kaempferol completely in mature leaves. Besides that, kaempferol (flavonol) can be induced when leaves are exposed to UV-B radiation (Lake et al. 2009; Mazid et al.2011). Kaempferol and naringenin are stored in vacuole to avoid harmful effect against cells (Roytrakul \& Verpoorte 2007).

Flavonoids including flavone, flavanone, flavanol, chalcone, isoflavone and isoflavanone are produced via shikimate and acetate-malonate biosynthetic pathway (Markham 1982). Most secondary metabolites including flavonoids and their glycosides are produced when tissues and organs are produced during plateau phase (Bar-Peled et al. 1993). Additionally, accumulation of secondary metabolites undergo during stationary phase of cell growth kinetics. Interestingly, many enzymatic activities are actively synthesized during this phase because secondary metabolites are more actively synthesized when carbon is no longer needed in large quantities for primary metabolites (Bourgaud et al. 2001). 


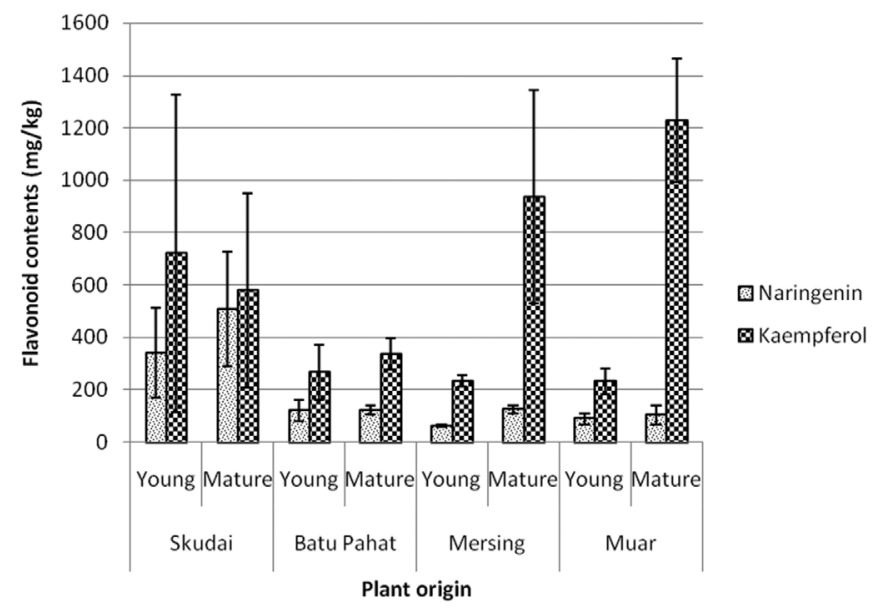

FIGURE 3. Naringenin and kaempferol contents in young and mature leaves extracts of $J$. gendarussa extracts from four different locations

\section{CONCLUSION}

$J$. gendarussa with high naringenin and kaempferol contents were successfully screened by GC-FID. Both compounds are found to be highly accumulated in mature organs i.e leaves. Further investigation such as plant tissue culture approach could be applied to optimize flavonoids content in vitro plants by manipulating medium composition and hormone concentration.

\section{ACKNOWLEDGEMENTS}

The authors would like to thank Universiti Teknologi Malaysia (UTM) and the Ministry of Higher Education (MOE) (MyPhD) for financial support and Plant Tissue Culture Laboratory, Faculty of Biosciences and Medical Engineering for lab facilities.

\section{REFERENCES}

Ayob, Z., Mohd Bohari, S.P., Abd Samad, A. \& Jamil, S. 2014. Cytotoxic activities against breast cancer cells of local Justicia gendarussa crude extracts. Evidence-Based Complementary and Alternative Medicine 2014: 1-12.

Ayob,Z., Abd Samad, A. \& Mohd Bohari, S.P. 2013. Cytotoxicity activities in local Justicia gendarussa crude extracts against human cancer cell lines. Jurnal Teknologi (Sciences and Engineering) 64(2): 45-52.

Bambang Prajogo, E.W., Guliet, D., Ferreira Queiroz, E., Wolfender, J.L., Noor Cholies, Z., Aucky, H. \& Hostettmann, K. 2009. Isolation of male antifertility compound in n-butanol fraction of Justicia gendarussa Burm. F. leaves. Folia Medica Indonesiana 45(1): 28-31.

Bar-Peled, M., Fluhr, R. \& Gressel, J. 1993. Juvenile-specific localization and accumulation of a rhamnosyltransferase and its bitter flavonoid in foliage, flowers and young citrus fruits. Plant Physiology 103: 1377-1384.

Bourgaud, F., Gravot, A., Milesi, S. \& Gontier, E. 2001. Production of plant secondary metabolites: A historical perspective. Plant Science 161: 839-851.

Cavia-Saiz, M., Busto, M.D., Pilar-Izquierdo, M.C., Ortega, N., Perez-Mateos, M.\& Mu niz P. 2010. Antioxidant properties, radical scavenging activity and biomolecule protection capacity of flavonoid naringenin and its glycoside naringin: A comparative study. Journal of the Science of Food and Agriculture 90: 1238-1244.

Chakravarty, A.K., Dastidar, P.P.G. \& Pakrashi, S.C. 1981. Simple aromatic amines from Justicia gendarussa ${ }^{13} \mathrm{C} N \mathrm{NR}$ spectra of the bases and their analogues. Tetrahedron 38(12): 1797-1802.

Figueiredo, C.A., Barroso, J.G., Pedro, L.G. \& Scheffer, J.J.C. 2008. Factors affecting secondary metabolites production in plants: Volatile components and essentials oils. Flavour and Fragrance Journal 23: 213-226.

Forkmann, G. 1991. Flavonoids as flower pigments: The formation of the natural spectrum and its extension by genetic engineering. Plant Breeding 106: 1-26.

Janarthanam, B. \& Sumathi, E. 2010. In vitro regeneration of Justicia gendarussa Burm. f. Libyan Agriculture Research Center Journal International 1: 284-287.

Kanno, S., Tomizawa, A., Hiura, T., Osanai, Y., Shouji, A., Ujibe, M., Ohtake, T., Kimura, K. \& Ishikawa, M. 2005. Inhibitory effects of naringenin on tumor growth in human cancer cell lines and sarcoma S-180-implanted mice. Biological and Pharmaceutical Bulletin 28(3): 527-530.

Kim, K.T., Yeo, E.Y., Moon, S.H., Cho, S.G., Han, Y.S., Nah, S.Y. \& Paik, H.D. 2008. Inhibitory effects of naringenin, kaempferol and apigenin on cholesterol biosynthesis in HepG2 and MCF-7 cells. Food Science and Biotechnology 17(6): 1361-1364.

Kong, K.W., Khoo, H.E., Prasad, N.K., Chew, L.Y. \& Amin, I. 2013. Total phenolics and antioxidant activities of Pouteria campechiana fruit parts. Sains Malaysiana 42(2): 123-127.

Krishna, K.L., Mehta, T.A. \& Patel, J.A. 2010a. In vitro hepatoprotective activity of Justica gendarussa stem on isolated rat hepatocytes. Pharmacologyonline 2: 9-13.

Krishna, K.L., Mruthunjaya, K. \& Jagruti,A.P. 2010b. Antioxidant and hepatoprotective potential of stem methanolic extract of Justicia gendarussa Burm. International Journal of Pharmacology 6: 72-80.

Lake, J.A., Field, K.J., Davey, M.P., Beerling, D.J. \& Lomax, B.H. 2009. Metabolomic and physiological responses reveal multi-phasic acclimation of Arabidopsis thaliana to chronic UV radiation. Plant, Cell and Environment 32: 1377-1389. 
Markham, K.R. 1982. Techniques of Flavonoid Identification. New York: Academic Press. p. 1.

Mazid, M., Khan, T.A. \& Mohammad, F. 2011 . Role of secondary metabolites in defence mechanism of plants. Biology and Medicine 3: 232-249.

Mustafa, R.A., Abdul Hamid, A.A., Mohamed, S. \& Bakar, E.A. 2010. Total phenolic compounds, flavonoids, and radical scavenging activity of 21 selected tropical plants. Journal of Food Science 75: 28-35.

Pallant, J. 2007. SPSS Survival Manual. New York: McGrawHill. pp. 232-257.

Periyanayagam, K., Umamaheswari, B., Suseela, L., Padmini, M. \& Ismail, M. 2009. Evaluation of antiangiogenic effect of the leaves Justicia gendarussa (Burm F) (acanthaceae) by chrio allontoic membrane method. American Journal of Infectious Disease 5(3): 187-189.

Roytrakul, S.\& Verpoorte, R. 2007. Role of vacuolar transporter proteins in plant secondary metabolites: Catharanthus roseus cell culture. Phytochemistry Reviews 6: 383-396.

Salimon, J., Mohd Noor, D.Z., Nazrizawati, A.T., Mohd Firdaus, M.Y. \& Noraishah, A. 2010. Fatty acid composition and physicochemical properties of Malaysian castor bean Ricinus communis L. seed oil. Sains Malaysiana 39(5): 761-764.

Sarju, N., Abd Samad, A., Abd Ghani, M. \& Ahmad, F. 2012. Detection and quantification of naringenin and kaempferol in Melastoma decemfidum extracts by GC-FID and GC-MS . Acta Chromatographica 24: 221-228.

Sharma, K.K., Saikia, K., Kotoky, J., Kalita, J.C. \& Devi, R. 2011. Anti-fungal activity of Solanum melongena L., Lawsonia inermis L. and Justicia gendarussa B. against dermatophytes. International Journal of PharmTech Research 3(3): 1635-1640.

Subramanian, N., Jothimanivannan, C. \& Moorthy, K. 2012. Antimicrobial activity and preliminary phytochemical screening of Justicia gendarussa (Burm. f.) against human pathogens. Asian Journal of Pharmaceutical and Clinical Research 5(3): 229-233.
Thomas, T.D. \& Yoichiro, H. 2010. In vitro propagation for the conservation of a rare medicinal plant Justicia gendarussa Burm.f. by nodal explants and shoot regeneration from callus. Acta Physiologiae Plantarum 32: 943-950.

Tu, Y.C., Lian, T.W., Yen, J.H., Chen, Z.T. \& Wu, M.J. 2007. Antiatherogenic effects of kaempferol and rhamnocitrin. Journal of Agricultural and Food Chemistry 55: 9969-9976.

Zhang, Y., Chen, A.Y., Li, M., Chen, C. \& Yao, Q. 2008. Ginkgo biloba extract kaempferol inhibits cell proliferation and induces apoptosis in pancreatic cancer cells. Journal of Surgical Research 148: 17-23.

Zahidah Ayob

Faculty of Biosciences and Medical Engineering

Universiti Teknologi Malaysia

81310 Johor Bahru, Johor Darul Takzim

Malaysia

Shajarahtunnur Jamil \& Farediah Ahmad

Department of Chemistry, Faculty of Science

Universiti Teknologi Malaysia

81310 Johor Bahru, Johor Darul Takzim

Malaysia

Siti Pauliena Mohd Bohari \& Azman Abd Samad*

Department of Biotechnology and Medical Engineering

Faculty of Biosciences and Medical Engineering

Universiti Teknologi Malaysia

81310 Johor Bahru, Johor Darul Takzim

Malaysia

*Corresponding author; email: azmansamad@utm.my

Received: 26 May 2016

Accepted: 11 July 2016 